\section{E-LOGOS}

ELECTRONIC JOURNAL FOR PHILOSOPHY ISSN 1211-0442

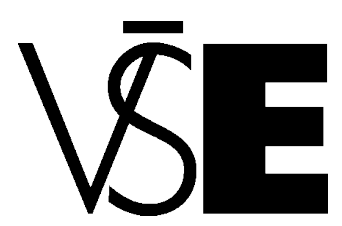

University of Economics

Prague

\title{
Smích v tematizaci estetiky
}

Jiří Vaněk

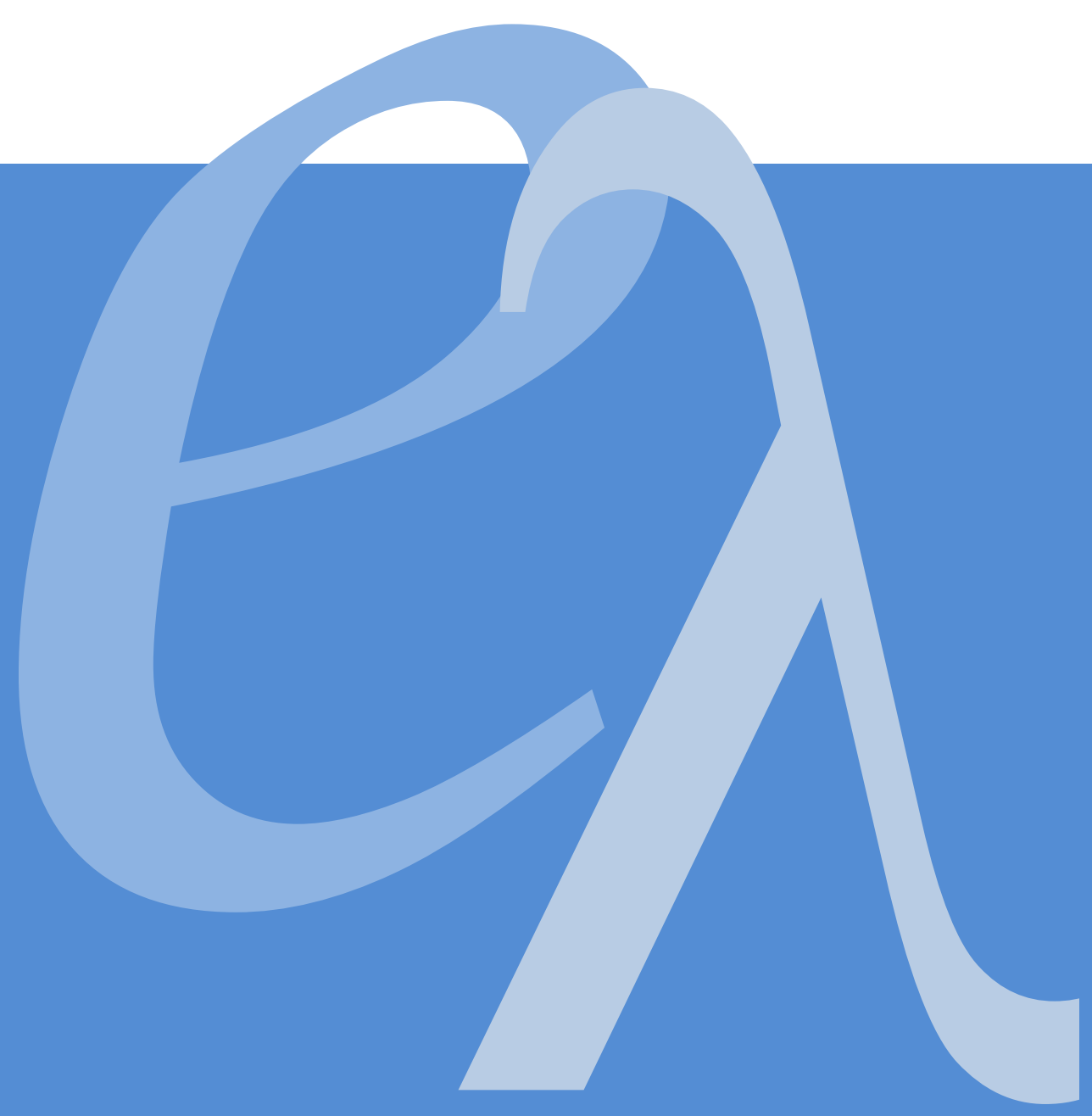




\begin{abstract}
The study attempts at a critical evaluation of the classical philosophical concept of laughter. Bergson and his predecessors (Hobbes, Stendhal, Baudelaire) treated laughter as derision, as an expression of one's superiority over his/her neighbour; in contrast with it, Karel Kosík refers to laughter's other anthropological meanings. The author tries the show that, in fact, there exists a lot of various modes of the phenomenon of laughter and, correspondingly, a lot of specific possibilities of aesthetic distance.
\end{abstract}

Keywords: laughter - derision - smile - Bergson - Hobbes - Stendhal - Baudelaire Karel Kosík - personal superiority - varieties of laughing behavior

\begin{abstract}
Abstrakt
Studie je pokusem o zhodnocení klasického filosofického pojetí smíchu. Bergson a jeho předchůdci (Hobbes, Stendhal, Baudelaire) jej zvažovali jako výraz a způsob zakoušení nadřazenosti: smích jako výsměch. Ve srovnání s nimi Karel Kosík odkazuje $\mathrm{k}$ dalším antropologickým významům. V této studii se poukazuje $\mathrm{k}$ rozmanitosti varietních podob tohoto fenoménu a specifickým možnostem estetické distance $\mathrm{v}$ těchto případech.
\end{abstract}

Klíčová slova: smích - výsměch - úsměv - humor - Bergson - Hobbes - Stendhal Baudelaire - Karel Kosík - osobní nadřazenost - rozmanitost smíchového jednání 
Sluší se úvodem vymezit výchozí pojmy alespoň „pracovními“ definicemi, jež si nečiní nárok na vyčerpávající úplnost, ale alespoň vyznačí základní významové směřování úvahy. Komiku chápeme jako charakteristiku směšné nepřiměřenosti, nesourodosti, humor jako schopnost objevit a komentovat komické situace, smích mentálně způsobený máme za projev reagující na zjištěnou komičnost, ironii za skrytý smích s odstupem, při němž zdánlivě vážně tvrdíme o věcech to, čeho opak je pravdou. Když Bergson vydal svůj útlý svazek zabývající se povahou směšného a komického, byly už k dispozici koncepce mnohem starší. Přesto patří toto dílko k základním příspěvkům, zvažujícím téma na pomezí estetiky a sociální psychologie. Francouzský filosof Henri Bergson byl možná nejvlivnějším evropským myslitelem na počátku dvacátého století. Jako jeden z představitelů tzv. filosofie života vychází z vnitřní zkušenosti o světě a prohlašuje za jeho základ „životní sílu“ (élan vital), jenž je zdrojem "tvořivého vývoje“. Časovou charakteristikou veškeré reality je nepřetržité „trvání", nikoliv porcovaně vnímaný čas, jaký nám zprostředkovává náš intelekt. Na rozdíl od intelektu, jenž vznikl pro praktickou životní orientaci, je pouze intuice s to rozpoznat podstatu skutečnosti. Vnější prostorové oddělování věcí a každé zmechanizování životního běhu neodpovídá pravé povaze života. $Z$ této filosofie vyvěrá i Bergsonovo pojetí smíchu, jeho podstaty a role v životě člověka. Vyjádřil je ve slavné knížce nazvané Smích (prvně vyd. 1899) a opatřené podtitulem Esej o významu komična:

„Život i společnost vyžaduje od každého z nás stálou, bdělou pozornost, která rozlišuje obrysy dané situace, jakož i určitou pružnost těla a ducha, jež nám umožňuje přizpůsobit se situaci. Napětí a pružnost jsou dvě vzájemně se doplňující síly, o něž v životě jde. Chybí tělu? - Jsou tu různé nehody, neduhy, nemoc. A duchu? Tady vystupují všechny stupně duševní chudoby, různé varianty šílenství. A konečně charakteru? Zde jejich nedostatek znamená hlubokou nepřizpůsobivost společenskému životu, zdroje ubohosti, někdy i přiležitost k zločinu. Odstraníme-li tyto nedostatky z vážného života (a ony mají tendenci odstranit se samy v průběhu čehosi, co nazýváme bojem o život), může postava žít, žít ve společnosti s jinými. Společnost však vyžaduje ještě něco jiného. Nestačí jí jen žít, chce žít dobře. A ted' se musí obávat, že se každý z nás spokojí s tím, že bude věnovat pozornost pouze tomu, co je nezbytné k životu, a zbytek přenechá automatismu zaběhnutých návyků. Musí se obávat i toho, že její členové se místo usilování o co nejjemnější rovnováhu vưlí, aby stále přesněji zapadaly jedna do druhé, spokojí jen s respektováním základních podmínek této rovnováhy. “1 Bergsonova estetika je takto zakotvena v jeho metafyzice, tj. názoru o základní povaze světa. Jeho dynamická podstata je biomorfní a tudíž pouhá mechanika je v něm překážkou svou toporností. Jako žádoucí se pak nabízejí takové rysy jako je plynulost, ladnost, pružnost a hbitost, vlastnosti patřící

\footnotetext{
${ }^{1}$ Bergson, H.: Smích, Naše vojsko, Praha 1993, s. 21.
} 
kráse a půvabu. Kladné estetické hodnoty př́imo vyvěrají z nároků, jež klade život sám. Společnost je specifickým rozvinutím životních procesů a tak smích, reagující na existenční nezbytnosti je potažmo i sociálním korektivem nepovedených a nevyhovujících počinů:

„Nestačí vytvořená shoda mezi lidmi, je zapotřebí stálého úsilí, vzájemné přizpůsobivosti. Každá tuhost charakteru, ducha a dokonce i těla bude společnosti podezřelá, nebot' je možnou známkou usínající činnosti, činnosti, jež se izoluje a má tendenci vzdalovat se od společného středu, kolem něhož se společnost otáčí, a je tedy konečně známkou odstředivosti. Společnost zde nemůže zasáhnout materiální represí, jelikož není materiálně uzpo̊sobená. Tyto známky v ní vyvolávají něco, co ji zneklidňuje pouze jako příznak - stěží jako hrozba, nanejvýš coby gesto. Odpoví tedy pouhým gestem. Smích je asi podobného druhu - forma společenského gesta. Obavou, která ji inspiruje, potlačuje krajnosti, udržuje bdělost a distanci od spojení s odpovídajícími podřadnými činy, jež by se mohly izolovat či uspávat, nakonec zpružňuje zbytek mechanické tuhosti společenského tělesa. Smích nevzniká z čisté estetiky, třebaže sleduje (neuvědoměle a v některých případech i imorálně) užitečný cíl všeobecného zdokonalení. Něco z estetiky však v sobě má, nebot' komično se rodí přesně v okamžiku, kdy společnost či osoba, zbavené starosti o své zachování, začnou vůči sobě jednat jako vůči uměleckým dílům. Zkrátka, opíšeme-li kruh kolem činů a sklonů, které kompromitují život jedince nebo společnosti, kolem činů, jež se svými přirozenými důsledky trestají samy, zůstane mimo toto území emocí a boje, v neutrální zóně, kde člověk člověku hraje divadlo, určitá tuhost těla, ducha a charakteru, kterou by společnost ještě chtěla eliminovat, aby u svých členů dosáhla největší pružnosti a nejvyšší možné společenskosti. Tato tuhost je komická a smích je trestem za ni. “2

Bergson takto uvažuje o smíchu jakožto lidské reakci na určité situace, jež nazýváme směšnými, komickými. Za dva základní objektivní zdroje vzniku takových situací pokládá „mechanismus začleněný do př́rody“ a "automatický řád společnosti“. Konkrétní komické situace jsou různými variantami a kombinacemi prýštícími z těchto pramenů. Vždy je to tedy nějaká „mechanická slupka na živém organismu“, jež vyvolává smích. Bergson uvádí různé dílčí vzorce tohoto celkového paradigmatu a ve všech běží o podnět $k$ přenosu pozornosti $z$ něčeho živějšího či hodnotově vyššího na cosi druhořadějšího, kupř. z obsahu na pouhou formu (at' už proto, že zrovna navzájem neladí, anebo že je pouhá forma upřednostněna na úkor obsahu).

Jako zdroje komického jsou tedy vyznačeny přesuny zájmu: 1. z těla na oblek (nesoulad mezi oděvem a tělem přenáší těžiště vnímatelovy pozornosti především na

\footnotetext{
${ }^{2}$ Tamtéž, s. 21-22.
} 
ten oděv), 2. z duše na tělo („komická je každá okolnost, která upoutá naši pozornost na fyzickou stránku osoby, když jde o stránku morální“) a 3. z osoby na věc (,když v nás osoba vzbuzuje dojem věci“).

Při podrobnějším pozastavení nad komikou situační a slovní probírá Bergson tři modelové případy: 1. „čertík na péro“, 2. "loutka“ a 3. „sněhová koule“.

V prvém případě jde o mechaniku opakování, jeden z obvyklých postupů klasické komedie. Mohou se opakovat úkony nebo výroky. „V komickém opakování výroků jsou nyní obecně vzato dvě složky, potlačený cit, který se vymrštuje jako pružina, a myšlenka, jež se baví opětovným potlačováním tohoto citu. “3

Model „loutka“ je rovněž užíván v komediích: postava se domnívá, že mluví a jedná svobodně, a zatím je pouhou hračkou v rukou někoho jiného jako „panáček na nitce“. Dynamika svobodného života je opět převedena na mechaniku loutkovitosti. Dodejme: to hra typu manipulace, pozorovaná bez soucitu, tu působí komicky.

Vzorec „sněhová koule“ představuje „vidinu účinku, který narůstá sám sebou, takže přičina na počátku nerozeznatelná dospěje nevyhnutelným způsobem $\mathrm{k}$ výsledku stejně důležitému jako nečekanému. “4 ${ }^{4}$ Tedy princip neúměrného zveličování, jev nečekaně nabobtnávající ve svých rozměrech či důsledcích. Domyslíme-li věc dále, nutno tuto charakteristiku doplnit: aby mohla taková událost vyvolat komický dojem, musí mít drobný, nebo alespoň neškodný dosah. Již sama sněhová koule změnivší se v hrozivou lavinu je pramálo žertovným útvarem a v oboru estetické recepce přechází do okruhu hororů. Vzpomeneme-li si na známou tezi z teorie chaosu a fraktálů, že závan motýlích křídel na jednom místě naší planety může (přesně podle modelu sněhové koule) způsobit ničivé vichřice na opačné straně zeměkoule, smích nás trochu přejde.

Obecně však lze říci, že různé složitější kombinace, odstíny a odliky takových původně jednoduchých postupů vytvářejí komiku. Kromě uvedených vzorců mezi takové postupy náleží i princip zvratu a výskyt téže situace ve dvou na sobě nezávislých sledech událostí, tudíž ve dvojím, zcela odlišném smyslu (odtud motiv „nedorozumění“!).

Přeneseme-li se z Bergsonova výkladu k širším souvislostem, jistě si lze představit, že i další uváděné situace mohou v člověku vzbuzovat také jinou reakci než smích (např. již zmíněná manipulace). Zejména mají-li určitý dramatický obsah, mohou být vnímány tragicky. K tomu, abychom se jim smáli, musí být pospolu s objektivními podmínkami i podmínky subjektivní. Bergson sám jmenuje tři: 1 . subjektem smíchu může být podle něj jen člověk, komično je výhradně lidské; 2. necitlivost vůči tomu,

\footnotetext{
3 Tamtéž, s. 41.
}

${ }^{4}$ Tamtéž, s. 44. 
co se odehrává a komu se to děje; 3. rozum zbavený citu musí zůstat v kontaktu s rozumy druhých, nebot' smích potřebuje ozvěnu. Zatímco Bergson je pojímá jako obecně platné předpoklady vzniku smíchu, volili bychom raději jejich odstíněnější vymezení.

Prvá z těchto podmínek může být ovšem chápána též jako podnět $\mathrm{k}$ úvaze o možnostech výrazu smíchové aktivity u zvířat: mnozí příslušníci fauny se vskutku smějí, ta příbuznost jejich výrazu a lidského vzezření je velmi vemlouvavá. Zde nám však jde o lidský smích a tak berme Bergsonovo stanovisko jen jako připomínka terénu prováděné analýzy.

Druhá je ovšem zvlášt' závažná, jde-li o pozici, kdy se směji druhému (nebo dané okolnosti, bez citového zájmu o osoby v ní zúčastněné), či se mu dokonce vysmívám. Je-li to ovšem zlobný, opovržlivě pohrdlivý smích, chovám se vskutku k předmětu svého výsměchu - řečeno s Bergsonem - „jako k uměleckému dílu“? Jen pokud jsem zaujat tímto předmětem bez své praktické afektivní zátěže, toliko osobou či situací jako takovou, je splněn předpoklad pro samostatnou estetickou reakci. Tehdy je tu zjevná distance, ono dálkové vedení estetické reakce.

Základním problémem Bergsonova př́istupu je, že těžiště smíchu vůbec spatřuje jen v pobaveném výsměchu. A ti, kteří se nad tímto fenoménem zamýšleli před ním, mu v tom také povětšinou předcházeli. Jmenujme alespoň Hobbese, Stendhala a Baudelaira. Oproti celkové Bergsonově koncepci mají jejich poukazy charakter dílčích inspirací, jež pomáhají nahlédnout jednotlivé životní stránky smíchové situace.

Thomas Hobbes ve svém spise $O$ člověku pojímá smích jako výraz radosti nad vlastním úspěchem nebo cizím neúspěchem či nedostatkem: "Jestliže někdo vysloví nějaký výrok nebo udělá, jak se mu zdá, nějaký vznešený čin, má sklon se smát. Stejně tak, jestliže někdo jiný řekne či udělá něco nevhodného, ten, který se ve srovnání s ním stává lepším než dřív, se sotva může zdržet úsměvu. Všeobecně spočívá cit smějících se $\mathrm{v}$ náhlém nabytí vlastní hodnoty následkem cizího nevhodného chování. Smějeme se tedy převážně jen tomu, co přijde náhle: titíž lidé se nesmějí téže věci ani témuž žertu víckrát. Avšak nevhodnému chování přátel a pokrevných příbuzných se nesmějeme, protože to nejsou cizí lidé. Smích tedy vyvolává spojení tři věcí: něčeho nevhodného, cizího a náhlého. “ ${ }^{5}$ Souznačně s tím charakterizuje Hobbes smích i ve svém nejslavnějším díle Leviathan: „Náhlý záchvat samolibosti je vášeň, která způsobuje ty pohyby lícních svalů, kterým říkáme smích. Je vzbuzena bud' nějakým nenadálým vlastním úspěchem, který nás potěší, nebo tušením nějaké vady u bližního, jejíž pozorování nám zalichotí. Napadá hlavně ty, kteří si uvědomují své skrovné přednosti a proto se udržují v dobré míře

\footnotetext{
${ }^{5}$ Hobbes, T.: Výbor z díla, Svoboda, Praha 1988, s. 113-114.
} 
vyhledáváním nedokonalosti u jiných. A tak mnoho smíchu nad vadami bližních je jen známka vlastní malomyslnosti. “6

Přestože se více zaměřuje na smíškovu výsměšnou roli, poukazuje Hobbes i ke smíchu jako výtvoru radosti. Společným jmenovatelem zůstává postoj nadřazenosti, at' již v důsledku vlastního zdařilého výkonu, nebo kvůli pocitu převahy nad nezdarem někoho druhého (pokud nás k němu nepoutá pozitivní citový vztah). Je to především jediný způsob malodušných, jak se vyvyšovat, když jim chybí skutečné zásluhy a opravdové hodnoty. Pak je smích jen výrazem samolibé pýchy: nevhodnost může být trapná nebo vzbudí napětí atp., ale smích vyvolá jen při nadneseném pocitu vlastní povýšenosti ve spojení s překvapivě náhlou nečekaností daného jevu a necitlivostí, absencí soucitu. Hobbes při svém pojednání o smíchu jmenuje i úsměv, ale ani ten zde není vůbec zmiňován ve své časté společenské roli jakožto výraz otevřenosti druhým (roli psychologické i estetické zároveň), když vyjadřuje sympatie, libost, přístupnost, přestup přes hranice vlastního já (tudíž je zde tedy distance od sebezavinutosti v prožívání).

Stendhal ve svých esejích $O$ smíchu a Smích trochu oprašuje Hobbesovo stanovisko, ale něco z obecných principů také sám přidává: za hlavní podmínky komična pokládá jasnost a nepředvídanost. Rovněž jsou podle něj nutné $\mathrm{k}$ smíchu detaily, podrobnosti, kdežto všeobecnosti nás nerozesmějí: smíchovou reakcí jsme poutáni ke konkrétnu reality.

Z řady jeho jemných dílčích postřehů stojí za to povšimnout si tohoto názoru: "Osoby, jíž se mám smát, si musím do určité míry vážit. " ${ }^{7} \mathrm{~V}$ této striktní formulaci je především skryta myšlenka, kterou si často, když se něčemu smějeme, ani výslovně neuvědomujeme: ve smíchu je kus obecnějšího (tj. nad rámec pouhého přítomného pocitu převahy) srovnání sebe sama s vysmívaným (tj. i v záchvěvu nadřazenosti je stále ještě ozvěna hodnoty, nad niž se takto pomyslně povyšuji!).

Také Charles Baudelaire v eseji O podstatě smíchu a obecně o komičnu ve výtvarném umění se ztotožňuje s hlediskem, podle něhož "smích pramení z představy vlastní nadřazenosti. “8 ${ }^{8}$ Komiku pak prohlašuje za jednu $z$ nejzřetelnějších satanských známek člověka. I estetika smíchu je tedy u Baudelaira součástí estetiky zla. Komické vzniká poměřováním, je jedním z plodů relativity: proto moudrý se směje vždy se strachem a z pohledu absolutního vědění a absolutní moci by komika zmizela. Baudelaire tímto názorem také odlišuje smích od radosti. Radost je podle něj jednotná, spočívá v sobě, kdežto smích „je výraz citu podvojného nebo rozporného;

\footnotetext{
${ }^{6}$ Hobbes, T.: Leviathan neboli o podstatě, zrízení a moci státu církevního a občanského, Melantrich, Praha 1941, s. 99-100.

${ }^{7}$ Stendhal: $O$ smíchu, Československý spisovatel, Praha 1958, s. 28.

${ }^{8}$ Baudelaire, Ch.: Úvahy o některých současnících, Odeon, Praha 1968, s. 231.
} 
právě proto v něm jde o křeč. “9 ${ }^{9}$ Tou rozeklaností je míněno propojení mezi hodnocením objektu jako komického a skrytým povýšeným sebehodnocením právě ve srovnání s tím komickým jevem. Tahle skrumáž přichází Baudelairovi na mysl především proto, že zvažuje výsměch člověka adresovaný druhému člověku. Z nízkého ocejchování smíchu a prožitku komického se však vyvazuje grotesknost. Ta se vyznačuje komickou nadsázkou; není již pouhým konstatováním jevu, ale svobodnou umělcovou tvorbou - za příklad slouží Rabelaisovo dílo. Nicméně i umělec tu čerpá ze svého podvojného přístupu, jenž tkví v tom, že charakteristiku svého tématu formuluje zároveň z pozice nadřazenosti.

Tradičně se tudíž zvažovala jen jedna poloha smíchu. Vesměs v tom postrádáme rozlišení mezi různými druhy a odstíny smíchového chování, vycházejícího z překvapení, údivu, souznění atd. Na širší rejstřík tohoto fenoménu upozornil již Karel Čapek: „Škála smíchu je stejně obsáhlá jako škála slzy: od vznešeného až k hnusu, od harf andělských až do skřeku Stanova, od vrcholů radosti do propasti nenávisti a zoufalství. “10 Nověji Karel Kosík poukázal k rozmanitým posunům lidské mysli ve smíchu, ale také k jeho sociálnímu a mentálnímu smyslu. V pospolitém smíchu spatřuje hodnotu prostředku, jímž se odhaluje nepřiměřenost. Tehdy "se účastníci ujišt'ují jak o své omylnosti, konečnosti, smrtelnosti, a tedy i směšnosti, tak o své důstojnosti a rovnosti, o svém nezadatelném lidství. “11 Dodejme, že může také mnohdy vyjadřovat jen sounáležitost duševně chabého společenství, jakým je rozchechtaná tlupa, nedorostlá vyšších pater lidského rozumu, at' již jsou to opilci, „fanoušci“ nebo političtí fanatici. Jestliže se v enigmatickém, záhadném úsměvu (kdo by nepomyslel na Monu Lisu, ale také už na nejstarší archaické řecké sochy kúrů a koré!) zračí vědomost o záhadách života, pravým opakem je dnešní „společenské“ „keep smilling“, jímž je prázdné povrchní zdání povýšeno nad skutečnost, když exhibice vystř́idala opravdovost, "maska a funkce se hodnotí výše než lidskost.“ ${ }^{12}$ Nutno však opět doplnit: v zaměstnanecké etiketě plynoucí z profesní etiky si dovedeme představit postoj zaujaté profesionální pozice, v níž převáží povinnost reprezentace firmy nad osobní naladěností; pak úsměv vyžadovaný pracovní pozicí vykazuje ve styku s druhými oddanost zvolené činnosti a je v něm něco hlubšího, nebot' není jen vynucený, strojený a neupřímný.

V jeho pozitivní roli lze smích pokládat za „podstatnou a trvalou složku demokratického pobytu na světě“ a humor chápat jako „uznání a přiznání

${ }^{9}$ Tamtéž, s. 235.

${ }^{10}$ Čapek, K,: O humoru, Snaha 18., 22. 8. 1908; cit. podle: Slavík, J.- Opelík, J.: Josef Čapek, Torst, Praha 1996, s. 42.

${ }^{11}$ Kosík, K.: O smíchu, in: týž, Století Markéty Samsové, Český spisovatel, Praha 1993, s. 189.

12 Tamtéž, s. 195. 
důstojnosti člověka skrze smích a smíchem“.13 Kosík spolu s tím odkazuje k významu "být dobré mysli“, tedy k mentálnímu stavu dosahujícímu svobodomyslnosti, která nachází svo̊j projev v jednotě duševního a tělesného: „Smích je rozpoložení mysli, které se zrcadlí v tělesnosti, v oduševnělé tělesnosti nebo tělesné duchovnosti onoho orgánu člověka, v němž tělesno a duch j e $\mathrm{d} n \mathrm{o}$ jsou: v oku. Úsměv je souhra očí a úst. “14

Vyvstává otázka, jak rozmanité chápání komiky chápat z hlediska estetických zážitků. Pokusme se v tom lépe vyznat, použijeme-li jako výkladový klíč směr významového odstupu návazně na pojem estetické distance. Estetická distance jakožto nutný odstup od zakoušeného objektu znamená oproštění od praktických zřretelů a pouhého bezprostřednîho fyziologického proživání. V jejích mezích však lze rozpoznat různé významové vektory, mentální směrování subjektu zaostřená na "posuzovaný“ objekt, jež vystupují v estetické recepci jako rozmanitá tematizace. V případech smíchu se naskýtá vektor vertikální, jehož kolmice ovšem může být subjektem prožívána směrem vzhůru i naopak dolů, anebo vektor horizontální. Na vertikální linii vyjadřovali někteří protagonisté moderního titanismu, k němuž náleželi spisovatelé jako lord Byron, Shelley nebo z jiné strany Lautréamont, vzdorovitý výsměch svrchovaným silám př́rody a vesmíru, v němž se pojila vypínavost poraněné subjektivity s vyhraněnou potřebou suverénní svobody nepodrobené nadřazeným řádům. ${ }^{15}$ Může být však na vertikále i v obráceném směru, seshora na člověka, tj. z pomyslného osudu dolů, na mne, jemuž se něco pokazilo či nepovedlo - když se zasmějeme vlastnímu nezdaru: tehdy se vysmíváme sami sobě, sebe klademe pod (svůj) úsudek, který vlastně připisujeme Osudu nebo druhým jako soud nad námi, stavíme se pomyslně do jejich pozice. Tomu odpovídá někdy případné pokárání: „Proč se ponižuješ?", nesouhlasí.li někdo s naší smíchovou sebekritikou.

A pak ona nejčastěji v teorii smíchu tematizovaná varianta výsměšného jednání vůči druhému člověku spojená s pocitem nadřazenosti, to je na distanční vertikále obrat dolů: přistupuji $\mathrm{k}$ druhému jako $\mathrm{k}$ věci. I v tomto vektorovém napětí je ovšem řada možných odstínů: výsměch, nadřazený úsměv, ironicky skrytý posměšek, skeptický úsměšek, na druhé straně až k pomezí žertu a vulgárnosti jako např́klad na obraze rudolfinského manýristy Hanse von Aachena SMĚJÍCÍ SE SEDLÁCI, kde nechybí ani doprovodné, provokativně diváka hanobící gesto rukou. Vyskytuje se však také zobjektivizovaná stupnice hodnot - ve srovnání nesourodých okolností:

\footnotetext{
${ }^{13}$ Kosík, K.: O Havlíčkově demokratismu, in: týž, Století Markéty Samsové, Český spisovatel, Praha 1993, s. 149.

14 Kosík, K.: O smíchu, in: týž, Století Markéty Samsové, Český spisovatel, Praha 1993, s. 195.

${ }^{15}$ Srv. analýzy titanismu V. Černého, viz Černý, V.: Soustavný přehled obecných dějin literatury naši vzdělanosti, sv. 4, Academia, Praha 2009, s. 351n.
} 
smích vzbuzený srovnáním dvou rozdílných úrovní, at již jde o osobu nebo situaci. Na tom principu jsou založeny groteskní obrazy, v nichž se zvírata chovají jako lidská společnost. Např́iklad na obraze vlámského barokního malîře Davida Teinerse ml. INTERIÉR S OPICEMI v šatech a kloboucích vyšňořená opičí čeládka hoduje a nastavuje tak zrcadlo světu lidskému, jehož vážnost zpětně uvádí v pochybnost.

Celou rozsáhlou stupnici odstínů zážitkového pole lze rozpoznat rovněž při horizontální distanční poloze: smích společný nad nějakou věcí, smích družné spolčenosti, vyznačující zároveň sounáležitost mezi smějícími se; ten může být souběžně výsměchem něčemu, pak je současně kolektivním vertikálním postojem ve vztahu k poníženému; často je tomu tak, nebot' se (třebas jen lehce, poněkud povznášejícím způsobem) vymezujeme jako společenství vůči směšnému. Vlastní horizontální smích je čistě výraz radosti ze života, ze sdílení vitálních sil, stmelující bližní v zážitku, ale ozývá se mnohdy také upadlý způsob smíchu: chechtot, jenž v př́ípadě družného sdílení vypovídá o nejnižší úrovni psychického dění, o primitivismu, jenž je promrháním možností lidské kultivace, halasné sebeuspokojení ztopené ve ztučnělých mozcích, známé například z veřejných projevů hřmotně hlučné chásky zahraničních turistů.

Smích jako vyjádření vzájemné družnosti tedy může být kombinován s výrazem spolčení proti někomu, jenž je vysmíván. $V$ opačném zaměření se projeví smích soucitný. Ženy dobře vědí, že lze smát-se-k-vábení. Varianty se mohou křížit, v prožitku se pak vrství a překrývají různé pozice. Podle naznačených rozlišovacích kritérií lze pak zařadit rozmanité další projevy smíchové mentální aktivity: škálu smíchu od souznělého posměvačného chechtotu (jako na obraze Ilji Repina ZÁPOROŽŠTÍ KOZÁCI PÍŠÍ TURECKÉMU SULTÁNOVI VÝSMĚŠNÝ DOPIS, 1891), šklebivého výsměchu (na způsob již zmíněných Aachenových Smějících se sedláků), rozesmáté radostnosti (jak také předvádí von Aachen $\mathrm{v}$ AUTOPORTRÉTU $S$ „DONNOU VENUSTOU“ z r. 1585), škádlivého zasmání (což opět ukazuje von Aachen dvojitým autoportrétem SMĚJÍCI SE HOŠI z doby kolem 1575), po bujarý burácivý chechtot nekontrolující se rozvernosti, spontánnosti propadlé řehonění se, stávající se soběstačným výrazem sebeprosazující se veselosti, hrubozrnnou křepčící roztlemenost (sedláci $\mathrm{v}$ hospodě na mnoha obrazech barokních vlámských a nizozemských mistrů jako byli Adriaen Brouwer nebo Jan Steen), po úsměšek, ale i rozesmátost společnosti, pro niž společný smích může působit jako výraz vzájemnosti a pojítka, leč také $\mathrm{v}$ jiné poloze jako spolčenost proti někomu, vůči němuž je smích namířen, tedy opravdu jako výsměch, šaškovský smích obrácený na dvě strany: ve zlehčené podobě prezentující sebe, ale ve šklebu namířený mimo sebe (jako kdysi u šašků na panovnickém dvoře ke králi), po smích jako vábničku, po skeptický úsměv jako intelektuálský výkon, vyjadřující vyhraněnější odstup a individualistické gesto. Jako protipól živočišné bujaré rozvernosti se vyskytoval smích degenerující v nervózní „uctivé“ pochechtávání, jež má vyjadřovat naopak 
ponížený sestup z vážnosti a jakési bezzubé sebeponížení, prostředek společenské komunikace měšt'anské vrstvy starších generací, výraz měštácké malosti a předstírané pochlebné servility (proto se objevuje ve filmech pro pamětníky z tohoto prostředí): je to mělké chichotání svědčící o pramálo zakalené mysli, jaksi vašnostovské, kondelíkovsky pokrotlé, pad’ourské (jako by říkalo „já tě nesežeru, jsem bezzubý, neškodný“)

A jak je tomu u smíchu nikoliv svrchu nadřazeného, nýbrž přátelského, "dobráckého", družně spoluprožívajícího (třebas s povzdechem: „No, to jsme tedy dopadli!“)? Zde se projevuje spíše než necitlivost jakási citová povznesenost, analogická té, kdy se smíchem se jen já sám vymaňuji z područí nějaké nelibé situace. Jsou ovšem ještě další polohy smíchu, jež se Bergsonově formuli vymykají. Především je to vstřícný úsměv provázející rozumění a srozumění. Ten po estetické stránce není výrazem nadřazenosti, ale otevřenosti - druhému člověku nebo věcem, $\mathrm{k}$ nimž přistupuji. Pak jsem nikoliv "nad“ nimi (povznesen), ale jen bez prakticky rabovačského př́istupu se taktně v rozumění přibližuji jejich jádru.

V těch různých variantách prožitků se mnohdy také vytrácí ona Bergsonem proklamovaná nutnost necitelnosti vůči objektu smíchové reakce. Zážitek komického údajně vylučuje citovou vazbu. Ve skutečnosti však může někdo (často např́klad naše dítě) působit mile komicky a zaznamenáme-li takovou situaci, dokonce to $\mathrm{v}$ pozorovateli ještě posílí emocionální vroucnost.

Postavit se takříkajíc nad věc pomocí smíchu mohu společně s někým, ale také pouze sám. Jedná-li se však jen o osamocený smích, prolamuje se problém třetí subjektivní podmínky formulované Bergsonem. Podle něj je smějící se rozum vždy v souznějícím kontaktu s jinými posměváčky a tato družná racionální ekologie tvoří živnou půdou pro existenci smíchu. Přesto by Bergsonova třetí podmínka nemusela být tolik omezena ve své platnosti jako jeho podmínka druhá, nýbrž stačí ji patrně modifikovat: i když se směji sám, odehrává se to $\mathrm{v}$ mém vnitřním dialogu, $\mathrm{v}$ konfrontaci stanovisek - jednoho, jež je faktickou formulací mé situace, druhého, jež se nad ni povznáší. $V$ povznesenosti smíchem je, třebas nevyslovena, zamlčeně přítomna takováto konfrontace mých postojů, tedy chcete-li - vnitřních rozumů, z nichž jeden přijímá holou skutečnost, druhý se z ní vyvazuje.

Smích představuje určitý odstup, distanci - od toho, co považuji za nevážné, ale je to jiný vztah k „nevážnosti“ než u hry. Tam jsem její součástí, jak do ní vstupuji (dobrovolně, pokud nejsem objektem hrové manipulace). U smíchu zaujímám distanční postoj vưči terénu mimo mne (výjimkou je sebeironie, výsměch různého stupně, jejž obracím proti sobě) - je to pozorovatelský, divácký postoj, jenž zrál 
v evropském iluzionismu, kritickém a skeptickém postoji vůči slabostem lidského světa. ${ }^{16}$

Za těchto okolností se však vyjevuje, že smích je spolu s psychologickou reakcí zároveň i reakcí estetickou. Proč? Když jsem v neblahé situaci stlačen "pod“ okolnostmi, mohu se trápit nebo rozčílit, ale v každém př́ípadě jsem tu do "toho“ potopen, jsem "v" těch okolnostech až po uši. Když se však tomu zasměji, povznesu se „nad“ situaci, právě už tím zasmáním se povznáším. Jsem ve vnitřním postavení nad sebou, $\mathrm{v}$ tom bídném stavu i nad tím, co mne sužuje či drtí. A v tomto psychologickém odstupu a nadhledu je přece, i kdyby jen v záblesku, vnímán jak celek mého vztahu k situaci, tak celek situace samé a já se té situaci svobodněji otevírám. A těmito rysy odstupu je přece jakožto estetická distance či otevřenost vnímanému bytí charakterizován estetický zážitek. Oproti tomu při rozhořčení nad danou situací nejde ani o negativní estetický zážitek ne-libosti, nebot' při něm nejsem $\mathrm{v}$ distančním postoji vůči situaci a nevztahuji se svobodně vůči jejímu celku (jsem „v tom" ponořen).

Právě pro tak zjevnou fyziologickou vazbu smíchu slyšíme varování: „Pláč a smích jsou esteticky klamné. Estetické gesto nikdy nepochází z melancholie či z úsměvu. A nemá s nimi nic společného. Všechno mistrovství vrhá chlad (Mallarmé) [...] Estetický požitek musí být založený na rozumové úvaze. “17 José Ortega y Gasset má na zřeteli, že jde o "sekundární emoce“, estetické city, při nichž se nevnímá věc, ale její idea. V souhlase $s$ tím řekněme to ještě jinak: je to reflexe prožitku směřující k propojení obecné stránky tohoto prožitku (což je spojeno s formou prožívaného) se sebereflexí. Ale to neznamená, že estetický zážitek může být jen v apollinském, s vnější odstupem vnímaném objektu. V dionýské podobě při niterné sebe si uvědomující prodlevě v prožitku lze rovněž dosáhnout estetických hodnot:

„Bereme-li za své formalistické koncepce bezzájmovosti, bude pro nás vskutku těžké smířit s nimi ony spíše dionýské umělecké idiomy. Tento problém však vzniká jen proto, že formalistické kritérium bezzájmovosti je psychologické, totiž že zahrnuje aktivní zaujetí kontemplativního postoje. Jak jsem ale ukázal jinde, kritérium estetické bezzájmovosti je př́ihodnější chápat v logickém smyslu. Proto mohou sice některé obrazy mít značnou užitnou hodnotu, přesto nás mohou těšit, aniž bychom tuto hodnotu zohlednili, nebo tak, že bude figurovat především jako zásadní prvek v rámci nějaké širší estetické jednoty. To rozhodně nepředpokládá žádný psychologický stav netečné kontemplace. I když je to touha po vítězství, která přiměje kmen $\mathrm{k}$ válečnému tanci, přesto mu mohou jeho účastníci plně propadnout a prožívat jeho rytmus a strhující drama pro ně samotné a nikoli pro jejich očekávané

\footnotetext{
${ }^{16}$ Viz Bartoš, J.: Ilusionismus, Aventinum, Praha 1927.

17 Ortega y Gasset, J.: Eseje o umeni, Archa, Bratislava 1994, s. 25 (citát přeložen do češtiny).
} 
praktické důsledky. V tomto případě je logická podstata vytržení tanečníků bezzájmová, i když mají jejich pocity dionýský charakter. Jak už jsem poukázal, právě moc takového estetického vytržení dokáže vysvětlit, proč se tanci a jiným formám artefaktuálního zobrazování připisuje vliv na praktické důsledky.

Bezzájmovost je tedy platným kritériem estetična, pokud se váže na logickou podstatu estetických reakcí, a nikoli na psychologický postoj, který údajně vyžadují. Tato interpretace ji zbavuje implicitně exkluzionistického západního elitářství.“18 Připustíme-li toto hledisko, pak tedy mentální prodleva u aktuálního prožitku aktivního účastníka může být specifickým způsobem prožitkové rozjímavosti.

Hustá škála možných smíchových zážitků, z nichž jsme stačili zmínit jistě jen část, se sice prvotně projevuje fyziologicky a psychologicky, avšak spolu s těmito projevy může vytanout $v$ jistém odstupu od nich (v estetické distanci) jejich prožitková sebereflexe, když u nich prodléváme a odstíněně je zakoušíme. Tehdy vystupují jako estetická hodnota. Jinak řečeno: Všechny tyto polohy lze zakoušet př́mo, ale také recipovat jako významové téma, jako sémantickou polohu smíchového jednání: vjeho zobrazení (uměnim) a v jeho prožitku, jenž se zaměř̀je na sebe sama.

${ }^{18}$ Crowther, P.: Kulturní vyloučení normativita a definice umění, in: Co je umění? (Texty angloamerické estetiky 20. století) ( Kulka, T.-Ciporanov D. eds.), Pavel Mervart, Červený Kostelec 2010, s. 419. 


\section{Bibliografie}

Bartoš, J.: Ilusionismus, Aventinum, Praha 1927.

Baudelaire, Ch.: Úvahy o některých současnících, Odeon, Praha 1968.

Bergson, H.: Smích, Naše vojsko, Praha 1993.

Crowther, P.: Kulturní vyloučení normativita a definice umění, in: Co je umění? (Texty angloamerické estetiky 20. století) ( Kulka, T.-Ciporanov D. eds.), Pavel Mervart, Červený Kostelec 2010.

Čapek, K,: O humoru, Snaha 18., 22. 8. 1908.

Černý, V.: Soustavný přehled obecných dějin literatury naší vzdělanosti, sv. 4, Academia, Praha 2009.

Hobbes, T.: Výbor z díla, Svoboda, Praha 1988.

Hobbes, T.: Leviathan neboli o podstatě, zř́zení a moci státu církevního a občanského, Melantrich, Praha 1941.

Kosík, K.: O Havlíčkově demokratismu, in: týž, Století Markéty Samsové, Český spisovatel, Praha 1993.

Kosík, K.: O smíchu, in: týž, Století Markéty Samsové, Český spisovatel, Praha 1993.

Ortega y Gasset, J.: Eseje o umení, Archa, Bratislava 1994.

Slavík, J.- Opelík, J.: Josef Čapek, Torst, Praha 1996.

Stendhal: O smíchu, Československý spisovatel, Praha 1958. 


\section{E-LOGOS}

ELECTRONIC JOURNAL FOR PHILOSOPHY

Ročník/Year: 2011 (vychází průběžně/ published continuously)

Místo vydání/Place of edition: Praha

ISSN 1211-0442

Vydává/Publisher:

Vysoká škola ekonomická v Praze / University of Economics, Prague

nám. W. Churchilla 4

Czech Republic

13067 Praha 3

IČ: 61384399

Web: http://e-logos.vse.cz

Redakce a technické informace/Editorial staff and technical information:

Miroslav Vacura

vacuram@vse.cz

Redakční rada/Board of editors:

Ladislav Benyovszky (FHS UK Praha, Czech Republic)

Ivan Blecha (FF UP Olomouc, Czech Republic)

Martin Hemelík (VŠP Jihlava, Czech Republic)

Angelo Marocco (Pontifical Athenaeum Regina Apostolorum, Rome, Italy)

Jozef Kelemen (FPF SU Opava, Czech Republic)

Daniel Kroupa (ZU Plzeň, Czech Republic)

Vladimír Kvasnička (FIIT STU Bratislava, Slovak Republic)

Jaroslav Novotný (FHS UK Praha, Czech Republic)

Jakub Novotný (VŠP Jihlava, Czech Republic)

Ján Pavlík (editor-in-chief) (VŠE Praha, Czech Republic)

Karel Pstružina (VŠE Praha, Czech Republic)

Miroslav Vacura (executive editor) (VŠE Praha, Czech Republic) 